\title{
Unexpected colonic perforation in a renal recipient: a case report
}

\author{
Böbrek nakli sonrası gelișen beklenmedik kolon perforasyonu: Olgu sunumu
}

\author{
Kürşat Rahmi SERİN, Metin KESKİN, Hüseyin BAKKALOĞLU, Fatih TUNCA, \\ Ali Emin AYDIN, Cumhur Uluğ ELDEGEZ
}

Gastrointestinal complications such as gastrointestinal bleeding and perforation due to immunosuppressant use are seen more frequently after solid organ transplantation. A 52-year-old male was admitted on the 7th day of a living donor renal transplantation with serous drainage at the incision site. He had no abdominal complaints. He was on triple immunosuppressant therapy. Abdominal plain X-ray and ultrasonography were normal, but diffuse extraluminal air was detected on the computed tomography scan. There were no pathological laboratory findings regarding the function of the renal allograft. We began the operation laparoscopically and then converted to laparotomy. Sigmoid colonic perforation was detected on the antimesenteric side. Neither diverticulitis nor ischemia was observed, and no evidence of iatrogenic injury was seen. There was no transrectal instrumentation history. Omentoplasty and sigmoid loop colostomy were performed. He was discharged on the 9th day following the operation. His colostomy was closed one year after the operation. Gastrointestinal complications can be fatal, but do not seem to influence the long-term survival or renal allograft function. Most of them are seen after using high doses of immunosuppressants to manage the early postoperative period or episodes of acute rejection. Early diagnosis and aggressive treatment play an important role in survival.

Key Words: Colonic perforation; colostomy; immunosuppression.
İmmünite baskılayıcı ilaçlara bağlı olarak gelişen gastrointestinal kanama ve perforasyon gibi komplikasyonlar sıklıkla solid organ nakli sonrası görülmektedir. Elli iki yaşında erkek hasta canlı vericiden böbrek naklinin 7. gününde yara yerinden akıntı şikayeti ile başvurdu. Herhangi bir karın ağrısı yoktu. Üçlü immünsupresan kullanmakta idi. Karın grafisi ve ultrasonografisi normal saptand 1 ancak bilgisayarlı tomografide karın içerisinde yaygın serbest hava görüldü. Transplante böbrek fonksiyonları da dahil olmak üzere laboratuvar incelemesinde herhangi bir patolojik bulgu saptanmadı. Tanısal laparoskopi sonrası açığa dönüldü. Antimezenterik yüzde sigmoid kolon perforasyonu vardı. Divertikülit ve iskemi bulgusu yoktu, travmaya ait bulgu da görülmedi. Transrektal enstrümentasyon anamnezi de yoktu. Omentoplasti ve sigmoid loop kolostomi yapildı. Ameliyatının dokuzuncu günüde hasta taburcu edildi. Ameliyatının birinci yılında da kolostomisi kapatıldı. Gastrointestinal komplikasyonlar ölümcül olabilir ancak uzun dönem sağkalımı ve gref fonksiyonunu etkilemedikleri bilinmektedir. Pekçoğu ameliyat sonrası erken dönem veya rejeksiyon atakları gibi yüksek doz immünite baskılayıcı ilaç kullanılan dönemde görülmektedir. Sağkalımda erken tanı ve tedavide agresif davranmak önemli rol oynar.

Anahtar Sözcükler: Kolon perforasyonu; kolostomi; immünsupresyon.
Following the development of solid organ transplantation, complications of transplantation surgery and postoperative medications have appeared. The most common early surgical complications of kidney transplantation are wound complications, bleeding and hematoma, acute vascular thrombosis, urine leak, ureteral stenosis, and lymphocele. Late-onset lymphocele, renal arterial stenosis and ureteral stenosis are common. ${ }^{[1]}$ Gastrointestinal (GI) complications such as bleeding or perforations are the most common lifethreatening surgical complications, ranging from 10 $20 \% .^{[2-5]}$ 


\section{CASE REPORT}

A 52-year-old male was admitted to our transplantation clinic on the 7th day of living donor-related renal allograft transplantation (right-sided, retroperitoneal approach surgery), after being discharged from a hospital in Egypt. He had end-stage renal failure because of diabetes and was on maintenance therapy by hemodialysis. On his physical examination, there was no finding implicating acute abdomen syndrome or infection. Only serous drainage at the incision was present, but there was no suspicion of intraabdominal infection or peritoneal dehiscence. Laboratory tests and radiological examination were planned for the next day and the patient went home. The same night, he was admitted to the emergency department because of mild abdominal pain. He had pain throughout the abdomen and nausea, and tenderness and rebound were detected. He had dyspnea due to pulmonary edema, but no fever was detected. He was taking methylprednisolone $(60 \mathrm{mg} /$ day $)$, mycophenolate mofetil (1 g/day) and tacrolimus ( $8 \mathrm{mg} /$ day). White blood cell count, abdominal X-ray, abdominal ultrasonography (US), and abdominal computed tomography (CT) were obtained. Leukocyte count was $20000 / \mathrm{mm}^{3}$ (normal range: 4000-10000), abdominal plain X-ray was normal, and there were no pathological findings on abdominal US. Diffuse extraluminal air in the abdomen was detected on CT (Fig. 1), but there was no fluid or collection. No abnormalities were found in his laboratory results to influence the function of the renal allograft. Under these findings (leukocytosis, rebound and CT findings), he was diagnosed with acute abdominal syndrome, and the reason was luminal organ perforation. We began the surgery laparoscopically, at the 24th hour of the onset of symptoms. There was purulent inflammatory fluid of about $20 \mathrm{cc}$ near the cecum and appendix. The rest of the abdominal cavity was clear, and no signs of inflammation were detected. Laparotomy was performed, and a sigmoid colon perforation, $3 \mathrm{~mm}$ in diameter, was seen on the an-

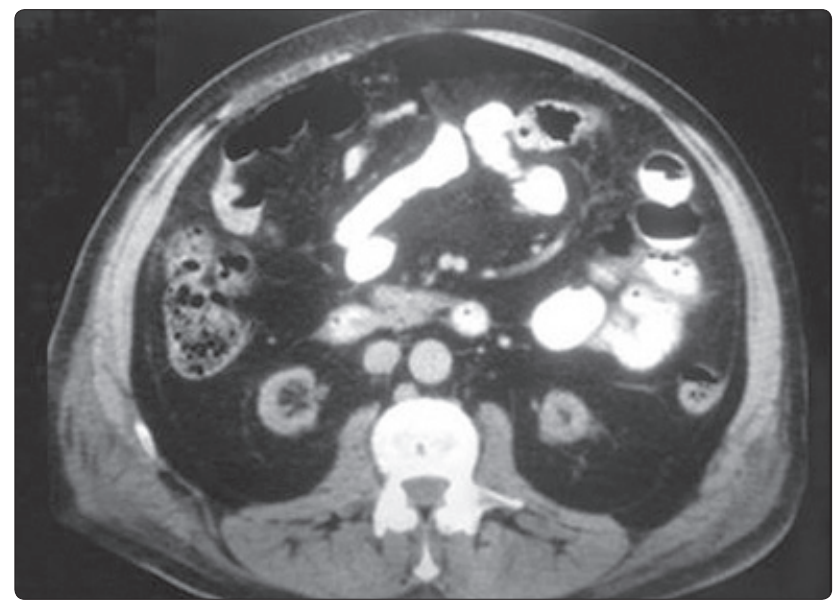

Fig. 1. Extraluminal air in the abdomen on CT. timesenteric side, near the cecum and appendix (Fig. $2)$. Neither diverticulitis nor ischemia was observed. There was no evidence of iatrogenic-traumatic injury, the whole peritoneum layer was intact, and there was no transrectal instrumentation history. The first surgery was performed with retroperitoneal approach from the right side. The perforated area was explored, and fluid was sampled for culture. The abdominal cavity was irrigated and drained. Exteriorization of the perforated site was not possible because of the edema. Omentoplasty was done, and sigmoid loop colostomy was performed proximal to the perforation area to decrease fecal contamination and divert the fecal passage. On the first day of the operation, leukocyte count was decreased to $13000 / \mathrm{mm}^{3}$, he had gas passage, and no complication was revealed concerning the renal allograft. Diuresis was forced because of the pulmonary edema. On the 2 nd day of the operation, he had defecation and began to take oral nutrition, and parenteral nutrition was stopped. Pseudomonas aeruginosa was identified on his intraabdominal fluid culture, and treated well with antibiotics. On the 8th day of the operation, the drains were removed, no surgical complication or renal allograft dysfunction was detected, the leukocyte count had regressed to 7800/ $\mathrm{mm}^{3}$, the C-reactive protein level was $4.2 \mathrm{mg} / \mathrm{L}$, and cytomegalovirus (CMV) antigens were negative. He was discharged from the hospital on the 9th day of the operation. His colostomy was closed one year after the operation (due to the patient's own hesitation). On his 40th-month follow-up, there was no problem related to the emergency GI surgery or renal allograft.

\section{DISCUSSION}

Colon perforation, especially iatrogenic, is a serious complication in the postoperative course of kidney transplantation. In the past three decades, the incidence has decreased from $1.4 \%$ to $0.67 \%$, and the mortality rate has improved from $70 \%$ to $32 \% \cdot{ }^{[3]}$ Approximately 300 renal transplantations were performed in

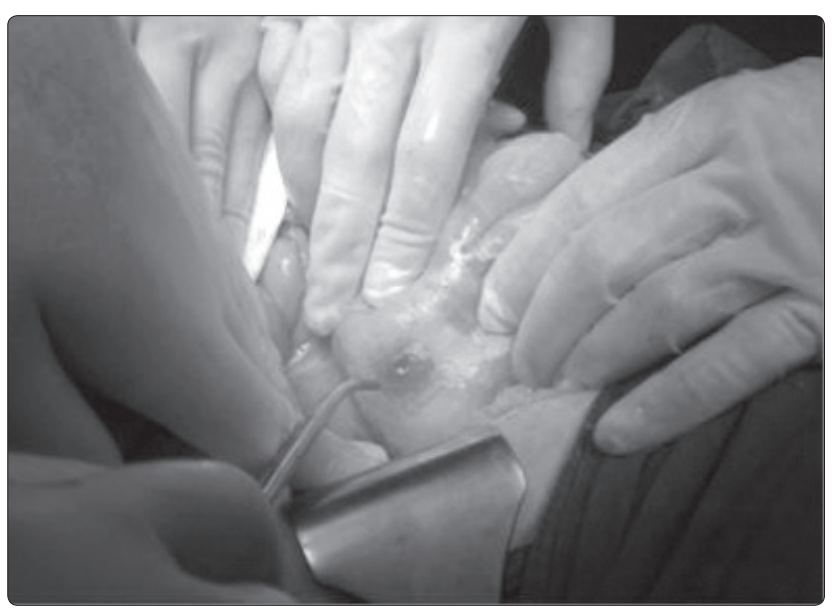

Fig. 2. Sigmoid colon perforation on the antimesenteric side. 
our clinic, and this patient was the first spontaneous colon perforation case due to high-dose immunosuppression. The most common cause of colon perforation is diverticulitis, and the most common site is the sigmoid colon. ${ }^{[3]}$ We did not find any causes such as diverticulitis or ischemic colitis. He had no transrectal instrumentation history, and there was no evidence of iatrogenic injury. We thus decided that our patient had spontaneous colonic perforation because of immunosuppressant use.

Spontaneous perforation of the GI tract after transplantation surgery is seen especially in the 3rd to 6th months of the transplantation because of the highdose immunosuppressant use, uremia and fecal impaction. In immunosuppressed patients, diagnosis of colonic perforation is a challenge. Abdominal pain, fever, tenderness, and leukocytosis are frequent in colonic perforation, but the clinical presentation in immunosuppressed patients may be atypical with vague abdominal symptoms. The symptoms are sparse and can be masked by the immunosuppressant, and the diagnosis is usually delayed. ${ }^{[6]}$ Nghiem et al. ${ }^{[1]}$ reported the average time of symptoms to surgery as 5.8 days. ReMine et al. ${ }^{[7]}$ reported the delay as less than 8.3 days in patients receiving greater than $20 \mathrm{mg}$ of prednisone daily. Successful management of the problem often depends upon early diagnosis and prompt therapy. Our patient was in the early period of transplantation. We have no information about the dosage of the induction therapy, although he had been taking high-dose triple therapy, as methylprednisolone (60 $\mathrm{mg}$ /day), mycophenolate mofetil ( $1 \mathrm{~g} /$ day) and tacrolimus ( 8 $\mathrm{mg}$ /day). He had typical symptoms such as abdominal pain, tenderness, and rebound, as well as leukocytosis.

The radiologic evaluation usually starts with plain $\mathrm{X}$-rays. Because of the challenge of the diagnosis in immunosuppressed patients based on physical examination and plain $\mathrm{X}$-ray findings, this can be followed by contrast administration orally and rectally under fluoroscopy or $\mathrm{CT} .{ }^{[8]}$ The CT diagnosis of perforation was based on direct and indirect findings. ${ }^{[8]}$ Extraluminal air under the diaphragm on plain X-ray can be identified in only $50-70 \%$ of these patients. CT is more sensitive in detecting extraluminal air and contrast. CT can also evaluate the bowel wall and extraintestinal structures. The most specific finding for GI perforation is the presence of extraluminal air, barium or radiocontrast fluid. ${ }^{[8]}$

In our patient, there were no pathological findings on plain X-ray or abdominal US. We performed abdominal CT, and found extraluminal air in the entire abdomen. No fluid or abscess was detected. All findings directed us to GI tract perforation, but there was no sign regarding the perforation site.
Diverticulitis, colorectal cancer, and idiopathic are the most common causes of colon perforation $(>60 \%$ of cases) ${ }^{[4,9]}$ Colonic ischemia, iatrogenic (especially during colonoscopy), infections (especially CMV), foreign body, trauma, and gynecological pathologies are other reasons. ${ }^{[10]}$ Spontaneous perforation of the colon, especially of the sigmoid colon, which was revealed as being related to immunosuppression, has been reported previously. ${ }^{[1,4,5,9]}$ Spontaneous perforation of the GI tract usually occurs in the early period after transplantation. The mean duration time is 3 to 6 months after transplantation. ${ }^{[5]}$ The differences in patient characteristics, such as medical problems, general condition, peritonitis grade, or cause of perforation, influence both the surgical decision and outcome. A cumulative effect of sepsis and medical conditions may be responsible for the high postoperative mortality, which ranges between $30-55 \% \cdot{ }^{[2,11]}$ Early diagnosis and surgical repair of perforations are the mainstays of treatment. To evaluate the current diagnosis and the level of the perforation, laparoscopy is a safe and minimally invasive diagnostic tool. Laparoscopy can also be therapeutic. ${ }^{[12]}$ In our patient, we used laparoscopy as a diagnostic tool to explore the abdominal cavity and to confirm and define the level of the perforation.

The optimal surgical approach to complicated colonic disease remains controversial. Without bowel preparation, intraluminal and intraperitoneal fecal contamination at the anastomotic site is the major problem when deciding the surgical technique. Hartmann's procedure has gained in popularity as an alternative to others, and currently, is the most commonly used technique for emergency colon surgery, especially in severely infected peritonitis. ${ }^{[13]}$ However, Hartmann's procedure has frequent complications, and the morbidity rate after restoration is high. ${ }^{[14]} \mathrm{A}$ randomized prospective study by Ravo et al. ${ }^{[15,16]}$ concluded that if feces could be excluded from intraluminal contact with the anastomotic site, an anastomosis can be performed safely even in the presence of peritonitis. Richter et al. ${ }^{[17]}$ reported a perforated sigmoid diverticulosis series with treatment by onestage sigmoid colon resection after peritoneal irrigation with saline in non-immunosuppressed patients. Nevertheless, many others have concluded that immunosuppression, septic shock, fecal peritonitis, or high cardiac risk patients at admission were correlated with higher morbidity and mortality rates, and that usage of a two-stage procedure with or without primary anastomosis would be safer than one-stage surgery. ${ }^{[1,5,16,18]}$ There is no comment about the timing of the second stage of the operation, but most of the authors favor delaying the second stage, usually preferring to perform it 6 months after the first stage. ${ }^{[14,18]}$

In conclusion, colon perforation due to immuno- 
suppressant use in renal allograft recipients is a rare but serious complication, with high mortality and morbidity rates. It must be diagnosed early and treated aggressively. With the improvements of antibiotics and immunosuppressants, the mortality and morbidity rates have been decreased in recent decades, but it can still be fatal.

Conflict-of-interest issues regarding the authorship or article: None declared.

\section{REFERENCES}

1. Nghiem DD, Corry RJ. Colorectal perforation in renal transplant recipients. Am Surg 1983;49:554-7.

2. Ponticelli C, Passerini P. Gastrointestinal complications in renal transplant recipients. Transpl Int 2005;18:643-50.

3. Konishi T, Watanabe T, Kitayama J, Shibahara J, Hiramatsu T, Hara K, et al. Successfully treated idiopathic rectosigmoid perforation 7 years after renal transplantation. J Gastroenterol 2004;39:484-9.

4. Biondo S, Parés D, Martí Ragué J, De Oca J, Toral D, Borobia FG, et al. Emergency operations for nondiverticular perforation of the left colon. Am J Surg 2002;183:256-60.

5. Meyers WC, Harris N, Stein S, Brooks M, Jones RS, Thompson WM, et al. Alimentary tract complications after renal transplantation. Ann Surg 1979;190:535-42.

6. Lederman ED, Conti DJ, Lempert N, Singh TP, Lee EC. Complicated diverticulitis following renal transplantation. Dis Colon Rectum 1998;41:613-8.

7. ReMine SG, McIlrath DC. Bowel perforation in steroidtreated patients. Ann Surg 1980;192:581-6.

8. Maniatis V, Chryssikopoulos H, Roussakis A, Kalamara C,
Kavadias S, Papadopoulos A, et al. Perforation of the alimentary tract: evaluation with computed tomography. Abdom Imaging 2000;25:373-9.

9. Carson SD, Krom RA, Uchida K, Yokota K, West JC, Weil R 3rd. Colon perforation after kidney transplantation. Ann Surg 1978;188:109-13.

10. Iqbal CW, Chun YS, Farley DR. Colonoscopic perforations: a retrospective review. J Gastrointest Surg 2005;9:1229-36.

11. Kriwanek S, Armbruster C, Dittrich K, Beckerhinn P. Perforated colorectal cancer. Dis Colon Rectum 1996;39:1409-14.

12. Geis WP, Kim HC. Use of laparoscopy in the diagnosis and treatment of patients with surgical abdominal sepsis. Surg Endosc 1995;9:178-82.

13. Finlay IG, Carter DC. A comparison of emergency resection and staged management in perforated diverticular disease. Dis Colon Rectum 1987;30:929-33.

14. Dalla Valle R, Capocasale E, Mazzoni MP, Busi N, Benozzi L, Sivelli R, et al. Acute diverticulitis with colon perforation in renal transplantation. Transplant Proc 2005;37:2507-10.

15. Ravo B, Metwally N, Castera P, Polansky PJ, Ger R. The importance of intraluminal anastomotic fecal contact and peritonitis in colonic anastomotic leakages. An experimental study. Dis Colon Rectum 1988;31:868-71.

16. Biondo S, Jaurrieta E, Martí Ragué J, Ramos E, Deiros M, Moreno P, et al. Role of resection and primary anastomosis of the left colon in the presence of peritonitis. Br J Surg 2000;87:1580-4.

17. Richter S, Lindemann W, Kollmar O, Pistorius GA, Maurer CA, Schilling MK. One-stage sigmoid colon resection for perforated sigmoid diverticulitis (Hinchey stages III and IV). World J Surg 2006;30:1027-32.

18. Seah DW, Ibrahim S, Tay KH. Hartmann procedure: is it still relevant today? ANZ J Surg 2005;75:436-40. 